\title{
Listing Requirements Lose IPO-Screening Functions: Evidence from the Emerging Growth Enterprise Market of China
}

\author{
Hai Long ${ }^{1} \&$ Zhaoyong Zhang $^{1}$ \\ ${ }^{1}$ School of Business, Edith Cowan University, Perth, Australia \\ Correspondence: Hai Long, School of Business, Edith Cowan University, Perth, Australia. E-mail: \\ soholonghai@163.com
}

Received: December 10, 2013

Accepted: January 9, $2014 \quad$ Online Published: February 25, 2014

doi:10.5539/ijef.v6n3p29

URL: http://dx.doi.org/10.5539/ijef.v6n3p29

\begin{abstract}
Using two multivariate regression models based on prior studies, this paper aims to examine whether the listing requirements of the GEMC are able to help the exchange to screen high quality IPO firms. It suggests that the approved IPO companies have better performances than failed ones, but listing requirements of the GEMC are unable to screen high quality issuers to go public, because the majority of listed companies performed poorly rather than better after their IPOs. This result is against previous findings that regard an IPO market as a screening device.
\end{abstract}

Keywords: listing requirements, IPO-screening functions, growth enterprise market, China

\section{Introduction}

Listing requirements, alternatively called listing standards, listing rules, or listing regulations, consist of two types of systems: original listing requirements and continued listing standards. This study concentrates on the original requirements for a company applying for its IPO. Exchanges usually have a wide variety of requirements for firms going public, including their revenue and profitability records, cash flow, public float, number of shareholders, market capitalization, underwriter's qualification, and so on. Such rules tend to be more flexible depending on listing venue, and are fairly rigorous in some more reputable exchanges.

These financial characteristics of listing requirements are very important for the issuers, public investors, and exchanges. A reputational exchange acts as a vital role in verifying quality of IPO applicants through original listing standards (Simon, 1989; Doidge et al., 2004; Harris, 2006). This certification function not only is conducive for an exchange to maintain its reputation and market integrity (Carpentier et al., 2010), but also as a mechanism protects potential investors and shareholders from unqualified issuers (Coffee, 2001; Carpentier et al., 2010). Consequently, exchanges may benefit from their prestige and well-performed listings, and then attracts more high quality of listings. In light of this, exchanges should have strong incentives to screen and accept high quality of listing applicants who are expected to enhance the reputation and influence of the exchanges.

The Growth Enterprise Market of China (GEMC) as a regulator and governor has a duty to protect each participant involving into this market. As Table 1 indicates, the GEMC has the most stringent listing standards to investigate IPO cases. According to the listing standards, issuing candidates are required to submit an IPO prospectus containing their audited financial statements, when they apply for IPOs. Through their earnings records, these candidates manage to convince an exchange of their reasonable fundraising purposes. The exchange adopts the financial determinants to measure the earnings potential of candidates, and their survival time on the securities market, in order to choose sustainable projects or firms to go public (Fama \& French, 2004). 
Table 1. Comparison of IPO listing requirements across stock exchanges

\begin{tabular}{|c|c|c|c|c|c|c|}
\hline Regions & IPO Markets & Business Ages & Fundraising Amount & Income & Profitability & Assets \\
\hline \multirow[t]{2}{*}{ China } & $\begin{array}{l}\text { The } \\
\text { Mainboard } \\
\text { (A Share) }\end{array}$ & Over 3 Years & Mini RMB $¥ 30$ million & $\begin{array}{l}\text { Business cash flow of net sum more than RMB } \\
50 \text { million in the three financial years, } \\
\text { altematively, at least RMB } 300 \text { million } \\
\text { accumulative income during this period; or }\end{array}$ & $\begin{array}{l}\text { Positive net profit each financial year in } \\
\text { the last three years and its accumulative } \\
\text { net profit above RMB } 30 \text { million. }\end{array}$ & $\begin{array}{l}\text { Intangible assets ratio to net } \\
\text { assets more than } 20 \% \text { in the } \\
\text { last financial statements. }\end{array}$ \\
\hline & The GEMC & Over 3 Years & Mini RMB \30 million & $\begin{array}{l}\text { Getting profitable with net profit of more than } \\
\text { RMBß5 milion since the last year, plus at least } \\
\text { RMB¥ } 50 \text { million income and income growth } \\
\text { rate above } 30 \% \text {; or }\end{array}$ & $\begin{array}{l}\text { Consecutive profitability with net profit of } \\
\text { more than RMB } 110 \text { million in the last } \\
\text { two years, and keeping growing in the } \\
\text { future. }\end{array}$ & $\begin{array}{l}\text { At least RMB } 20 \text { million of } \\
\text { net assets in the last financial } \\
\text { statements. }\end{array}$ \\
\hline \multirow[t]{4}{*}{ Hong Kong } & \multirow[t]{2}{*}{$\begin{array}{l}\text { The } \\
\text { Mainboard } \\
\text { (H Share) }\end{array}$} & Over 3 Years & Mini HK\$200 million. & $\mathrm{NA}$ & $\begin{array}{l}\text { At least } \mathrm{HK} \$ 20 \text { million in the last year, } \\
\text { and accumulated profit of at least } \mathrm{HK} \$ 30 \\
\text { million in the last two years. }\end{array}$ & NA \\
\hline & & & Mini HK\$4 million. & At least HK\$500 million & $\mathrm{NA}$ & \\
\hline & \multirow[t]{2}{*}{ The GEM } & 1 Year & Mini HKS500 million; or & $\begin{array}{l}\text { A turnover of at least HK\$500 million in the } \\
\text { last year; of }\end{array}$ & NA & $\begin{array}{l}\text { A total asset of at least } \\
\text { HKS } \$ 00 \text { million at the end of } \\
\text { the last financial year. }\end{array}$ \\
\hline & & 2 Yeas & Mini HK\$46 million. & NA & & $\mathrm{NA}$ \\
\hline \multirow[t]{4}{*}{ Singapore } & \multirow[t]{3}{*}{$\begin{array}{l}\text { The } \\
\text { Mainboard }\end{array}$} & 2 Years & $\mathrm{NA}$ & NA & $\begin{array}{l}\text { Accumulated profits in the last two years } \\
\text { more than } \$ \$ 10 \text { million }\end{array}$ & NA \\
\hline & & 3 Years & $\mathrm{NA}$ & NA & $\begin{array}{l}\text { Accumulated profits in the last three years } \\
\text { more than } \$ \$ 7.5 \text { million, plus at least } \\
\text { profit S\$1 million for each year. }\end{array}$ & NA \\
\hline & & $\mathrm{NA}$ & Minimum S\$80 million. & $\mathrm{NA}$ & $\mathrm{NA}$ & $\mathrm{NA}$ \\
\hline & The SESDAQ & $\mathrm{NA}$ & $\mathrm{NA}$ & $\mathrm{NA}$ & $\begin{array}{l}\text { No numerical requirements, but the issuers } \\
\text { are expected to be profitable and } \\
\text { demonstrate their prospective growth or } \\
\text { expansion. }\end{array}$ & NA \\
\hline \multirow[t]{4}{*}{ U.S.A } & \multirow[t]{4}{*}{$\begin{array}{l}\text { The American } \\
\text { Stock } \\
\text { Exchange }\end{array}$} & NA & $\mathrm{NA}$ & & $\begin{array}{l}\text { Pre-tax profit of at least USS750 thousand } \\
\text { required in the last fiscal year, or two of } \\
\text { the three most recent fiscal years. }\end{array}$ & $\begin{array}{l}\text { Total assets of at least USS4 } \\
\text { million. }\end{array}$ \\
\hline & & NA & Mini US\$50 million. & NA & NA & $\begin{array}{l}\text { Total assets of at least US\$4 } \\
\text { million. }\end{array}$ \\
\hline & & $\mathrm{NA}$ & Mini US\$75 million; or & Minimum USS75 million in revenues; or & NA & $\begin{array}{l}\text { Total assets of at least US\$75 } \\
\text { million. }\end{array}$ \\
\hline & & 2 Years & $\mathrm{NA}$ & NA & NA & $\begin{array}{l}\text { Total assets of at least US\$4 } \\
\text { million. }\end{array}$ \\
\hline U.K. & $\begin{array}{l}\text { The London } \\
\text { Stock } \\
\text { Exchange }\end{array}$ & At least 3 Years & $\begin{array}{l}\text { Minimum UKE } 700 \\
\text { thousand }\end{array}$ & $\begin{array}{l}\text { A revenue earning track record for the three } \\
\text { year period required but no a numerical } \\
\text { requiremen. }\end{array}$ & NA & $\begin{array}{l}\text { A track record of control over } \\
\text { the majority of assets for the } \\
\text { last three fiscal years, but no a } \\
\text { numerical requirement. }\end{array}$ \\
\hline
\end{tabular}

According to Tomas and Paul (2011), IPO markets act as a screening device can select potential firms to go public. Prior studies show that IPO firms in some Asian countries, such as Japan, Korea and Malaysia, perform better in the three-year post-IPO period (Kim et al., 1995; Paudyal et al., 1998). In light of these suggestions, I hypothesize that listing requirements of the GEMC are able to screen high quality issuers to go public, and stop unqualified ones from IPOs, and the post-issue performance of listed firms is better than their pre-issue performance. To do so, this study employs two regression models to examine the pre-IPO and post-IPO performances. According to the hypothesis, the post-IPO performances should be better than Post-IPO ones.

The results show that all IPO applicants met the minimum requirements, and the approved companies have better performances than failed ones. Unlike previous findings, the listing requirements of the GEMC are not helpful for select high quality IPO applicants to go public in a long run, because the listed firms underperformed within the last two years after their IPOs.

The significance of this study is extending prior literature on listing requirements of the Chinese IPO market. It is expect to exert potential impacts on policies and practices. Some IPO policies (including listing rules) for this new market are tentative and unsound, and need to be gradually modified and improved. This study provides the policy-makers with evidence to examine the feasibility and efficiency of the current listing requirements, so they are appropriately able to regulate the listing rules according to the empirical evidence.

The remainder of this paper is organized as follows: Section 2 outlines analytical framework. Section 3 describes the data and analysis. Section 4 presents the results. Section 5 summarizes the study.

\section{Research Design}

\subsection{Choices of Financial Determinants}

This study investigates the financial variables of listing standards for the emerging IPO market. Although there are many uncertain variables impacting IPO assessment, this study focuses on the listing-requirement-specific determinants: fundraising amount (FA), net profit (NP), profit growth rate (PGR), business income (IN), income 
growth rate (IGR) and net assets (NA).

These determinants are chosen due to two reasons. The GEMC has compulsory and rigorous requirements for them. Listing candidates in the market are subject to these minimum entry requirements, which are set out in the document 'Provisional Administration Regulations for Initial Public Offerings in Growth Enterprise Market' (PARIPO). This policy stipulates some primary and mandatory listing criteria to examine IPO cases. Therefore, these listing- requirement-based factors are the focal criteria that the IPO Committee consistently emphasizes.

Prior literature suggests these factors - net assets (Babich \& Sobel, 2004), profits (Firth, 1998; Keasey \& McGuinness, 1991), profit growth (Fischer, 2000; Pagano et al., 1998), are the most significant indicators to measure an IPO firm's earnings capacity and potential, which are consequently the most reliable and convincing evidence for a successful listing application. As Firth (1997) suggested, the financial performances of listed firms can reflect their long-run market performances. In addition, Long (2014) has investigated that the three determinants along with fundraising amount are the principal factors influencing IPOs in the GEMC. I incorporate two new factors (IN and IGR) into this study.

\subsection{Regression Models}

Adopting an analytical framework based on Chen et al. (2000), I use the multivariate regression models to test my hypothesis. I define it as:

$$
\begin{gathered}
\text { Pre } P=\beta_{0}+\beta_{1} \text { logpre } N P+\beta_{2} \text { prePGR }+\beta_{3} \text { logpreIN }+\beta_{4} \text { preIGR }+\beta_{5} \log \text { pre } N A+\beta_{6} \log F A \\
\text { Post } P=\gamma_{0}+\gamma_{1} \text { logpost } N P+\gamma_{2} \text { post } P G R+\gamma_{3} \operatorname{logpos} I N+\gamma_{4} \text { postIGR }+\gamma_{5} \operatorname{logpos} t N A+\gamma_{6} \log M C
\end{gathered}
$$

Where, PreP stands for pre-IPO performance of a firm;

logpreNP stands for the log of mean net profits before IPOs;

prePGR is the mean growth rate of the net profits during the period;

logpreIN is the log of mean business incomes before IPOs;

preIGR is the mean growth rate of the incomes before IPOs;

logpreNA is the log of mean net assets before IPOs;

$\log F A$ is the IPO fundraising amount.

PostP stands for post-IPO performance of a firm;

logpost $N P$ stands for the log of mean net profits after IPOs;

post $P G R$ is the mean growth rate of the net profits during the period;

logpostIN is the log of mean business incomes after IPOs;

postIGR is the mean growth rate of the incomes after IPOs;

logpost $N A$ is the log of mean net assets after IPOs;

$\log M C$ is the market capitalization of a public firm's shares.

According to my hypothesis, I can propose

$\mathrm{H}_{0}: \Delta \sum p=\sum_{n=1}^{k} \operatorname{PreP}_{n}-\sum_{n=1}^{k} \operatorname{Post}_{n}<0$. The post-ante characteristics perform better than ex-ante ones.

$\mathrm{H}_{1}: \Delta \sum p=\sum_{n=1}^{k} \operatorname{PreP}_{n}-\sum_{n=1}^{k} \operatorname{Post}_{n}>0$. The post-ante characteristics perform worse than ex-ante ones.

\section{Data and Analysis}

\subsection{Data}

According to the listing procedures of China's stock market, IPO firms have to apply for their IPO permission from the CSRC, and they have to specify their IPO-specific information in their IPO prospectus. The CSRC publishes those documents on its official website (www. csrc.gov.cn) for public investor's reference. The panel data used for this study was collected from these IPO prospectuses of listing applicants. The CSRC examined 243 IPO applications from September 2009 to December 2010, 205 of which have been listed on the GEMC, 38 of which were rejected by the CSRC. The post-IPO data on the proposed variables in 2011 and 2012 was collected as well.

\subsection{Descriptive Analysis}

\subsubsection{Industrial Distribution}

Table 2 presents an overview of industrial distribution on the approved IPO cases. The most striking feature is 
that manufacturing industry (advanced and traditional manufacture) dominates the emerging share market, with 62.13 percent $(62+28 / 243=62.13 \%)$ of approved firms and 32.9 percent $(22.9 \%+10 \%)$ passing rate, which are almost 6 times and 4 times of the counterparts (with $10.7 \%$ and $8.2 \%$ respectively) of the followed industry new materials. Thus, the GEMC is still a manufacture-oriented listing market. However, the new and technology-based industries have considerably limited number of applications $(0$ for both Astronautic \& Aeronautic and Marine Engineering industries, 5 cases for both new energy and modern agriculture, and 17 for IT), and passing rate $(2.1 \%, 2.1 \%$ and $7 \%$ respectively), but higher approval rate with 100 percent of industrial cases. China's economy structure is dominated by manufacturing industry, but the government has been conducting a pilot scheme of economy structure transition from the source-consumed to the source-saved economy. This transition needs a long period to be accomplished. Thus, the traditional and source-consumed industries are still active with $17.1 \%$ of listed firms in this market.

(Traditional manufacture 28+ Civil Engineering 1+Food 3+General Service 2+Restricted Sectors 1) / $205=17.1 \%$.

Table 2. Statistic of IPO approval by industries

\begin{tabular}{lllll}
\hline & Industries & Shortlist & Approval & P.R. $^{\text {a }}$ \\
\hline \multirow{3}{*}{ Two High } & Advanced Manufacture & 69 & 62 & $22.9 \%$ \\
Five New & Information Technology & 17 & 17 & $7.0 \%$ \\
Sectors & Biomedicine & 18 & 16 & $5.9 \%$ \\
& New Materials & 34 & 26 & $8.2 \%$ \\
& Modern Services & 44 & 29 & $7.9 \%$ \\
& Environment Friendly & 10 & 10 & $4.1 \%$ \\
& New Energy & 5 & 5 & $2.1 \%$ \\
& Modern Agriculture & 5 & 5 & $2.1 \%$ \\
& Astronautics \& Aeronautics & 0 & $/$ & $/$ \\
Traditional & Marine Engineering & 0 & $/$ & $/$ \\
& Traditional Manufacture & 32 & 28 & $10.0 \%$ \\
& Civil Public utility & 1 & 0 & $/$ \\
& Real Estate \& Civil Engineering & 1 & 1 & $0.4 \%$ \\
& Transportation & 0 & $/$ & $/$ \\
& Food & 3 & 3 & $1.2 \%$ \\
& General Services & 3 & 2 & $0.5 \%$ \\
& Restricted Industries & 1 & 1 & $0.4 \%$ \\
& Total Amount & 243 & 205 & \\
\hline
\end{tabular}

Note: a. P.R. (Passing Rate) $=$ passing rate in total $\mathrm{x}$ passing rate of industrial cases.

\subsubsection{Fulfillments of Listing Requirements}

According to the provision 10 in the PARIPO, it requires:

i) IPO candidates have consecutively been profitable in the last two years and the accumulated net profit amount was over RMB 10 million (1E7). Alternatively, the candidates just started to earn profit in the last year and their net profit was more than RMB 5 million, along with income of RMB 50 million in this year, plus over 30 percent of its annual growth rate in the last two years.

In the Np segment of Table 3, the minimum figures for approved IPOs are 1.03E7 and 1.82E7 for the last two years respectively, which for failed ones are 1.23E7 and 1.69E7 during the period. All of them are greater than the listing requirement of the profit over RMB 10 million.

ii) IPO candidates possess net assets valuing at over RMB 20 million (2E7) in the last financial statement prior to IPOs, without outstanding deficits.

In the NA segment of Table 3, the minimum figure for the approved IPOs is 4.21E7, which is significantly greater than the requirement of net assets. The minimum one for failed firms is 5E7. Therefore, both kinds of companies have a great deal of assets beyond the listing requirements. 
iii) The total share amount of IPO candidates is at least RMB 30 million (3E7) after going public.

Apparently, all IPO firms have met this requirement. The minimum one is $2.00 \mathrm{E} 8$.

In each variable, the approved firms had outstanding performance. For example, the mean value of the NP is 5.53E7, which was far greater than the failed firms' value 2.99E7. In terms of growth rate of income, this table indicates the vast majority of these applicants have significant income growth with mean rate over 30 percent, but only limited firms have negative increase. This may account for the fulfillment of listing requirements under term 10 in the PARIPO (e.g. firms just started to earn profit in the last year and its net profit was more than RMB 5 million, along with income of RMB 50 million in this year, plus over 30 percent of its annual growth rate in the last two years).

Table 3. Statistics of pre-IPO performances on failed and approved firms

\begin{tabular}{llllll}
\hline & & \multicolumn{3}{c}{ Pre-IPO Performances } \\
Variables & & Failed & \multicolumn{3}{c}{ Approved } \\
\hline \multirow{3}{*}{ IN } & Mean & 2009 & 2010 & 2009 & 2010 \\
IGR & Minimum & $1.84 \mathrm{E} 8$ & $2.52 \mathrm{E} 8$ & $2.72 \mathrm{E} 8$ & $3.01 \mathrm{E} 8$ \\
& Mean & 0.46 & $2.99 \mathrm{E} 7$ & $3.54 \mathrm{E} 7$ & $6.72 \mathrm{E} 7$ \\
& Minimum & -0.17 & -0.49 & 0.57 & 0.3 \\
NP & Mean & $2.38 \mathrm{E} 7$ & $2.99 \mathrm{E} 7$ & -0.24 & -0.82 \\
& Minimum & $1.23 \mathrm{E} 7$ & $1.69 \mathrm{E} 7$ & $1.03 \mathrm{E} 7$ & $5.53 \mathrm{E} 7$ \\
PGR & Mean & 0.46 & 0.49 & 0.57 & $1.82 \mathrm{E} 7$ \\
& Minimum & -0.17 & -0.42 & -0.24 & -0.82 \\
NA & Mean & $1.24 \mathrm{E} 8$ & $1.38 \mathrm{E} 8$ & $1.46 \mathrm{E} 8$ & $1.82 \mathrm{E} 8$ \\
& Minimum & $4.16 \mathrm{E} 7$ & $5.00 \mathrm{E} 7$ & $4.83 \mathrm{E} 7$ & $4.21 \mathrm{E} 7$ \\
FA (MC) & Mean & NA & & $7.79 \mathrm{E} 8$ & \\
& Minimum & NA & & $2.00 \mathrm{E} 8$ & \\
\hline
\end{tabular}

Therefore, all IPO candidates have met the minimum requirements of the financial determinants. Generally, the approved candidates had better performance than failed ones in these aspects.

\subsection{Regression Model Analysis}

Table 4. Results of multivariate regressions

\begin{tabular}{|c|c|c|c|c|c|c|c|c|c|c|c|c|c|c|}
\hline \multirow[b]{2}{*}{ Variables } & \multirow[b]{2}{*}{$\mathrm{N}$} & \multicolumn{4}{|c|}{ Coefficients $^{\mathrm{a}}$} & \multicolumn{2}{|c|}{ Minimum } & \multicolumn{2}{|c|}{ Maximum } & \multicolumn{2}{|c|}{ Mean } & \multicolumn{3}{|c|}{$\mathrm{t}$-test for Equality of Means } \\
\hline & & $\begin{array}{l}\text { B } \\
\text { (Pre) }\end{array}$ & $\begin{array}{l}\gamma \\
\text { (Pre) }\end{array}$ & $\mathrm{t}$ & Sig. & Pre & Post & Pre & Post & Pre & Post & $\begin{array}{l}\text { Mean } \\
\text { Difference }\end{array}$ & $\mathrm{t}$ & $\begin{array}{l}\text { Sig. (2 } \\
\text {-tailed) }\end{array}$ \\
\hline $\log I N$ & 205 & 1.01 & 0.89 & 9.44 & 0.001 & 7.48 & 7.32 & 10.36 & 12.22 & 8.372 & 8.452 & 0.08 & 3.037 & 0.003 \\
\hline IGR & 205 & 1.19 & 1.21 & 22.03 & 0 & -0.82 & -0.55 & 4.78 & 6.34 & 0.3319 & 0.41 & 0.078 & 2.22 & 0.027 \\
\hline $\log N P$ & 205 & 1.77 & 1.58 & 10.74 & 0 & 7.23 & 7.43 & 9.45 & 10.31 & 7.659 & 7.053 & -0.606 & 4.59 & 0 \\
\hline PGR & 205 & 1.04 & 1.27 & 18.32 & 0 & -1.03 & -0.16 & 3.85 & 4.66 & 0.4628 & 0.341 & -0.122 & 2.11 & 0.029 \\
\hline $\log \mathrm{NA}$ & 205 & 0.36 & 0.56 & 2.621 & 0.009 & 6.476 & 7.653 & 10.02 & 12.54 & 8.18 & 9.66 & 1.48 & 2.194 & 0.015 \\
\hline $\log F A$ & & & & & & & & & & & & & & \\
\hline$(\log M C)$ & 205 & 1.27 & 1.43 & 12.31 & 0 & 7.86 & 7.19 & 9.41 & 11.87 & 8.7468 & 8.34 & -0.407 & 12.77 & 0 \\
\hline Constant & & -2.67 & -2.28 & -3.24 & 0.002 & & & & & & & & & \\
\hline R2 & & $.918^{\mathrm{b}}$ & $.894^{\mathrm{c}}$ & & & & & & & & & & & \\
\hline $\mathrm{F}$ & & $502.32^{\mathrm{b}}$ & $303.22^{\mathrm{c}}$ & & $.000^{\mathrm{b}}$ & & & & & & & & & \\
\hline $\mathrm{P}$ & 205 & & & & & 24.77 & 23.97 & 41.02 & 38.69 & 33.696 & 31.764 & -1.932 & 5.58 & 0.002 \\
\hline$\sum P$ & 205 & & & & & & & & & 7884.78 & 7795.43 & -89.35 & & \\
\hline
\end{tabular}

a. Dependent Variable: PreP, PostP.

b. Predictors: (Constant), logpreFA, preIGR, logpreIN, prePGR, logpreNA, logpreNP.

c. Predictors: (Constant), logpostMC, postIGR, logpostIN, postPGR,logpostNA, logpostNP. 
Table 4 presents the results of multivariate regressions. The coefficient column shows that the variable $\log N P$ has the most contributions by $B 1.77$ and $\gamma 1.58$ to pre-IPO and post-IPO performances respectively. By contrast, the variable $\log N A$ has the least contributions to the performances. In addition, all these determinants are positively related to the listed firms' performances, because their coefficients are beyond zero. Moreover, $\mathrm{R}^{2}$ 0.918 and 0.894 for the two models demonstrate that these proposed variables can comprehensively account for the performances. The $F$ values 502.32 and 303.22 clearly show that the collected sample data have perfect goodness to their population. The Sig values of these coefficients are at very significant level less 0.05 .

The left columns present the results of performance and post performance. The mean difference column indicates that these variables logpostIN (0.08), IGR (0.078), and logpostNA (1.48) perform better than pre-IPO counterparts. However, these listed firms have poor performances in $\log N P$ and $P G R$ by -0.606 and -0.122 respectively. Meanwhile, a majority of market capitalization of shares decreases by -0.407 . Generally, the total value $P$ drops by -1.932 in the majority of listed firms. The general post-IPO performance of these listed firms is worse than pre-IPO performance, because of $\Delta \sum P(-89.35)<0$.

\section{Findings and Discussions}

\subsection{Industry Distribution}

The GEMC is overwhelmingly dominated by manufacturing industry with 41.56 percent (advanced manufacture $69+$ traditional manufacture $32 / 243=41.56 \%$ ), due to the context that China's economy is in the transitional process of industrialization. In addition, this industry has overwhelming IPO approval rate 32.9 percent, almost 4 times of the second approved industry. As a consequence, the GEMC like Chinese primary market is also a manufacture-dominated market.

In contrast, US sample by Kooli and Meknassi (2007) shows different patterns. During the period of 1985 to 2005, the IT-related industries dominated US IPO markets with 2061 firms at 33.06 percent of total successful IPOs, followed by the service-based sectors with 1593 cases at 25.55 percent. The manufacturing sector is the third one with 1394 issuers.

In addition, the biomedicine (BI) industry is a booming and profitable new industry in China, so it deserves high approval rate 88.89 percent. Followed by the environmentally friendly sector (EF), it is an emerging and fast-growing industry. As Dong and Michel (2012) suggested, IPOs from a growing industry are more likely to earn high return rate, and the industry growth is able to exert the largest economic impact on IPO long-run performance. My study confirms this viewpoint.

Therefore, the IPO approval rates vary across industry sectors. IPO firms achieve a successful listing application, apart from having good operating performances on their accounting indicators, they should be able to grasp the national macroeconomic direction, and keep pace with this macroeconomic tendency.

\subsection{Fulfillments of Listing Requirements}

Both approved and failed firms met the minimum requirements of net profit, net assets and fundraising amount. Apparently, the approved companies have better performances in these aspects than failed ones.

Profitability is reliable and significant evidence in signaling long-term performance after listing and potential returns of the issuing firms (Firth, 1998; Jain \& Kini, 1994), and its growth potential is one of the deterministic factors of going public (Fischer, 2000).

In terms of growth rate of net profit, the IPO firms had better performance on their net profit growth than income growth, which is partly due to the fact that the GEMC, unlike the primary markets, is a profit-preferred rather than firm-size-based market.

\subsection{Pre-IPO and Post-IPO Performances}

These listed firms have not shown a general upward trend, because their post-performance is not better than their pre-performance. This trend is reflected in most determinants, such as NP, PGR, and FA. This is due to the fact that these listed firms spent their IPO fund on their NA to expand their market share, regardless NP and PGR. This is a very popular marketing strategy in the Chinese product market. This strategy directly leads to the increases in IN and IGR, but results in the decreases in NP and PGR. The value-based investors will exit from their portfolios when they find these firms' profitability drops for a long run. Subsequently, the share prices of these firms drops, which consequently results in market capitalization drops as well.

Unlike IPO firms that perform better in the post-IPO period in other Asian stock markets, these GEMC listed firms do not present this good performance after their IPOs. As such, these results reject $\mathrm{H}_{0}$ : $\Delta \sum p=\sum_{n=1}^{k} \operatorname{PreP}_{n}-\sum_{n=1}^{k} \operatorname{Post}_{n}<0$, and accept $\mathrm{H}_{1}: \Delta \sum p=\sum_{n=1}^{k} \operatorname{PreP}_{n}-\sum_{n=1}^{k}$ Post $_{n}>0$. The post-ante 
characteristics perform worse than ex-ante ones.

The poor performance of post-IPOs in the GEMC is due to the fact that the economic and political factors impact on post-issue performance across the Chinese financial market (Chen et al., 2000), because this market is dominated by the State-Owned Enterprises. If some political factors were included into my model, the results would be different.

\section{Conclusion}

This study employs multivariate regression models to measure the performances of listed firms on the emerging IPO market GEMC. Through investigating the pre-IPO and post-IPO performances, this study aims to detect whether the listing requirements help the exchange to choose potential firms to go public. The results show all IPO applicants met the minimum listing requirements of the GEMC, but these listed firms generally underperformed in the listing- requirement-based aspects.

In light of this finding, I conclude that the listing requirements of GEMC lose IPO-screening functions, they are unable to choose fast-growing and value-based firms to go public, they are also unlikely to prevent the poor quality firms from IPOs, due to a number of reasons, particularly the industrial-orientation. This limitation of the study is the short span of post-IPO data, it is difficulty to measure the listed firms' growth potentials based on the limited data. Thus, the further study will be conducted with a long span of data and some political determinants.

\section{References}

Babich, V., \& Sobel, M. J. (2004). Pre-IPO operational and financial decisions. Management Science, 50, 935948. http://dx.doi.org/10.1287/mnsc.1040.0252

Carpentier, C., L'Her, J. F., \& Suret, J. M. (2010). Stock exchange markets for new ventures. Journal of Business Venturing, 25, 403-422. http://dx.doi.org/10.1016/j.jbusvent.2008.08.002

Chen, G. M., Firth, M., \& Kim, J. B. (2000). The post-issue market performance of initial public offerings in China's new stock markets. Review of Quantitative Finance and Accounting, 14, 319-339. http://dx.doi.org/10.1023/A:1008358609204

Coffee, J. C. (2001). The rise of dispersed ownership: The roles of law and the state in the separation of ownership and control. The Yale Law Journal, 111, 10-82. http://dx.doi.org/10.2307/797515

Doidge, C., Karolyi, G. A., \& Stulz, R. (2004). Why are foreign firms listed in the US: Worth more? Journal of Financial Economics, 71, 205-238. http://dx.doi.org/10.1016/S0304-405X(03)00183-1

Dong, M., \& Michel, J. S. (2012). Do industry growth prospects drive IPO stock performance? Working paper, York University. Retrieved from http://northernfinance.org/2012/program/papers/349.pdf

Fama, F., \& French, K. (2004). New lists: Fundamentals and survival rates. Journal of Financial Economics, 73, 229-269. http://dx.doi.org/10.1016/j.jfineco.2003.04.001

Firth, M. A. (1997). An analysis of the stock market performance of new issues in New Zealand. Pacific-Basin Finance Journal, 5, 63-85. http://dx.doi.org/10.1016/S0927-538X(96)00026-1

Firth, M. A. (1998). IPO profit forecasts and their role in signaling firm value and explaining post-listing returns. Applied Financial Economics, 8, 29-39. http://dx.doi.org/10.1080/096031098333221

Fischer, C. (2000). Why do companies go public? Empirical evidence from Germany's Neuer Market. Working paper, Ludwig-Maximilians-Universitat Munchen. http://dx.doi.org/10.2139/ssrn.229529

Harris, A. D. (2006). The impact of hot issue markets and noise traders on stock exchange listing standards. University of Toronto Law Journal, 56, 223-280. http://dx.doi.org/10.1353/tlj.2006.0010

Jain, B., \& Kini, O. (1994). The post-issue operating performance of IPO firms. The Journal of Finance, 49, 1699-1726. http://dx.doi.org/10.1111/j.1540-6261.1994.tb04778.x

Keasey, K., \& McGuinness, P. (1991). Prospectus earnings forecasts and the pricing of new issues on the unlisted securities market. Accounting and Business Research, 21, 133-145. http://dx.doi.org/10.1080/00014788.1991.9729826

Kim, J. B., Krinsky, I., \& Lee, J. (1995). The aftermarket performance of initial public offerings in Korea. Pacific-Basin Finance Journal, 3, 429-448. http://dx.doi.org/10.1016/0927-538X(95)00016-E

Kooli, M., \& Meknassi, S. (2007). The survival profile of US IPO issuers 1985-2005. The Journal of Wealth Management, 10, 105-119. http://dx.doi.org/10.3905/jwm.2007.690955 
Long, H. (2014). Exploring the principal factors influencing IPOs in the emerging growth enterprise market of China. International Journal of Trade, Economics and Finance, 5, 77-81. http://dx.doi.org/10.7763/IJTEF.2014.V5.344

Pagano, M. (1989). Trading volume and asset liquidity. The Quarterly Journal of Economics, 104, 255-274. http://dx.doi.org/10.2307/2937847

Paudyal, K., Saadouni, B., \& Briston, R. J. (1998). Privatization initial public offerings in Malaysia: Initial premium and long-term performance. Pacific-Basin Finance Journal, 6, 427-451. http://dx.doi.org/10.1016/S0927-538X(98)00018-3

Simon, C. (1989). The effect of the 1933 securities act on investor information and the performance of new issues. The American Economics Review, 79, 295-318. http://www.jstor.org/stable/1806847

Tomas, M., \& Paul, T. (2011). The IPO market as a screening device and the going public decision: Evidence from acquisition of privately and publicly held firms. Review of Quantitative Finance and Accounting, 37, 325-361. http://dx.doi.org/10.1007/s11156-010-0207-y

\section{Copyrights}

Copyright for this article is retained by the author(s), with first publication rights granted to the journal.

This is an open-access article distributed under the terms and conditions of the Creative Commons Attribution license (http://creativecommons.org/licenses/by/3.0/). 